University of Pennsylvania

From the SelectedWorks of David Grazian

2004

\title{
The Production of Popular Music as a Confidence Game: The Case of the Chicago Blues
}

David Grazian, University of Pennsylvania 


\title{
The Production of Popular Music as a Confidence Game: The Case of the Chicago Blues
}

\author{
David Grazian
}

In this article I argue that the production of live music shares many formal properties with that of confidence games: specifically, (1) a set of structural relationships in which operators, ropers, insiders, shills and marks are enmeshed, (2) the deployment of carefully planned strategies of deception, and (3) a pattern of success owed in part to the moral and financial motivations of insiders, the willingness of the state to assist in the enterprise, and the desire among victims to be swayed by the production. Drawing on ethnographic research conducted in some of Chicago's most popular blues clubs, I examine these three components of live music production qua confidence game. I also briefly discuss how one group of participantslocal blues musicians - reacts to their own performances as musicians/confidence artists. Finally, I conclude by exploring the broader implications this case suggests regarding other types of live music production.

KEY WORDS: culture; music; race; symbolic interaction; ethnography.

In leisure establishments such as restaurants, nightclubs and dancehalls, cultural producers provide entertainment for an audience of consumers desiring a certain kind of experience (be it romantic, exotic, efficient or otherwise), and enlist service workers with the task of manufacturing this experience as a seamless performance. At theme parks where children are approached by life-size cartoon characters, this fantasy world succeeds as such when the actors who play them are firmly hidden behind their furry costumes and masks; similarly, restaurants often keep kitchen work out of their patrons' line of sight. Even instances when these back stages are revealed to the audience are sometimes little more than nuanced and elaborate stagings themselves, as when restaurants with exhibition-style kitchens keep their dry-goods closets, staff locker rooms, roach spray and mousetraps out of view.

Correspondence should be directed to David Grazian, Sociology Department, University of Pennsylvania, 3718 Locust Walk, Philadelphia, PA 19104-6299; e-mail: dgrazian@soc.upenn.edu. 
A curious set of concerns develops in settings where patrons seek out cultural forms deemed "authentic," or naturally indigenous to their locale. In these settings, consumers expect to be entertained by performances that conform to dominant stereotypes of the setting, with attention given to local dialect, styles of interaction, dress and so forth. But in addition, they also expect that these performances will be real, as genuine expressions of self rather than a charade performed merely for the audience's benefit. As a result, producers face the arduous challenge of meeting a predetermined set of expectations without appearing as though such a feat requires any effort. While few contemporary consumers would be shocked by the revelation that motion pictures rely on tricky camerawork and special effects, or that their favorite actor routinely opts for plastic surgery, audiences rarely suspect that authentic culture and art-populist music, exotic handicrafts, ethnic cuisine-depend on similarly performative strategies of manipulation and impression management.

Sociologists and historians remind us that authenticity is not an objective quality inherent in things, but rather an argument that people make about the things in the world that they value. Like all subjective judgments or collective identities, authenticity operates as a kind of myth that cultural producers or authorities must "invent," "imagine," "stage," "fabricate," or otherwise manufacture if it is to serve as a persuasive representation of reality (Hobsbawm and Ranger 1983; Anderson 1991; MacCannell 1976; Peterson 1997). The socially constructed nature of authenticity presents an inviting puzzle for those who study the production of live popular music. Audiences often valorize forms of music that they deem authentically representative of a particular geographic region, folk culture or ethnic group. Authenticity in hip-hop is measured according to a performer's ability to "keep it real" by demonstrating his solidarity with "the street" (McLeod 1999), while folk music fans swoon to the proletarian charms of their working-class heroes (Cantwell 1996; Marcus 2001). But on the other hand, the contours of all popular music styles and genres are always manufactured and subject to change, including those valued for their authenticity such as country, folk and the blues (Keil 1966; Peterson 1978, 1997; DiMaggio 1987; Becker 1982; Roy 2002; Grazian 2003). As a result, debates concerning authenticity rage on within the worlds of all kinds of music, from the youthful sounds of punk, indie rock and electronic dance (Thornton 1996; Frank 1997; Azerrad 2001) to the more refined genres of baroque and classical music (Fruehwald 1988; Kenyon 1988; Leppard 1988; Kivy 1995).

In this article I argue that in their attempts to manufacture authenticity for the patrons of live music venues, cultural producers devise performances whose formal properties resemble traditional confidence games in which operators, ropers, insiders, shills and marks interact in a cultural ecology of deception and guile. As a means of exploring the similarities between confidence games and the production of popular music, I turn to the world of the Chicago blues club. By observing the interplay among club owners, boosters, musicians, support personnel and audience 
members, I develop a theory of active cultural production as a kind of collective strategy employed by multiple actors, all in search of authenticity as a commodity to be manufactured, exploited and consumed.

\section{THE CONFIDENCE GAME IN SOCIOLOGICAL THEORY}

Sociological research on the confidence game, or "con," began during the heyday of the Chicago school of urban sociology in the 1920s and 1930s. Arguably the two most well-known monographs of this era, The Gold Coast and the Slum and The Taxi-Dance Hall, characterize a wide variety of con artists and their games: street fakers and fortune tellers who lull customers into believing their powers; hawkers who sell snake oil on the sidewalk to unwitting passersby; cult leaders who convince their charges to take odd jobs and pay them their wages; and taxi-dancers who lure and eventually exploit male immigrants for financial gain (Zorbaugh [1929]1976; Cressey 1932). ${ }^{1}$

The Chicago tradition relied on an ecological model of interpersonal relations in which individuals "naturally" form groups and compete with one another for dominance within a temporal and spatial context of social, economic and environmental constraints (see Abbott 1997). This approach gave rise to what Norton Long (1958) referred to as an "ecology of games," a web of social relations in which actors behave "within an organized group activity that has goals, norms, strategies, and roles." This emphasis on the similarities between "games" and their less "trivial occupations," as expressed by Long (p. 252), finds its way into a host of more contemporary sociological endeavors, including symbolic interactionism (Goffman 1969), rational choice theory (Coleman 1990), organizational and network analysis (Padgett 1985; Padgett and Ansell 1993), and community affairs (Cornwell, Curry, and Schwirian 2003).

In particular, the confidence game has long served as a metaphor for impression management and other types of deceptive interaction rituals. ${ }^{2}$ Goffman (1959) uses the performances of double agents, shills, imposters and charlatans in order to illuminate the more common acts of duplicity employed in everyday affairs. In his theatrical universe, married couples serve as each other's accomplices during gossipy dinner parties, hairdressers help us misrepresent our true age, and parents protect their children by telling them white lies and other wellintentioned falsehoods. More pointedly, organizational sociology emphasizes how specific institutions rely on rhetorical strategies commensurate with the successful

\footnotetext{
${ }^{1}$ This work influenced later sociological research on confidence artists; for example, see Polsky (1969).

${ }^{2}$ As Polsky (1969, p. 53) argues in an aside in his essay on "The Hustler," "Of course, conning is only a matter of degree, in that all of us are concerned in many ways to manipulate others' impressions of us, and so one can, if one wishes, take the view that every man is at bottom a con man." For this reason, many successors to the Chicago tradition have always drawn on the confidence game as a model of human behavior.
} 
con in order to portray themselves in the most positive light, particularly by manipulating existing "definitions of the situation" through exaggerations of fact, strategies of misrepresentation and mystification, and sheer guile. Sociological accounts demonstrate how professionals expertly explain away their mistakes in the workplace (Hughes 1958; Bosk 1979), and how political actors rely on stagecraft to "govern by public relations" (Boorstin 1961; Rogin 1987; Suttles 1990; Klinenberg 2002).

While the confidence game is certainly applicable to these varied settings, the production of music serves as a particularly worthy context in which to employ the con as a theoretical model. The similarities between confidence games and rock concerts, discos, jazz clubs and even hootenannies are represented by much more than simply their reliance on general tactics of impression management, rhetoric and performativity. Rather, in the context of such enterprises a cultural ecology of deception entwines proprietors, promoters, performers, support personnel and patrons in a set of relations that bear an even closer resemblance to the confidence games played by traditional grifters and their marks. Specifically, the successful production of live popular music and cons both rely on (1) a set of structural relationships in which operators, ropers, insiders, shills and victims are enmeshed; (2) the deployment of carefully planned strategies of deception; and (3) a pattern of success owed in part to the moral and financial motivations of insiders, the willingness of the state to assist in the enterprise, and the desire among victims to be swayed by the production. ${ }^{3}$ In addition, the production of music, like hustling, seems to most easily develop in populated cities where bohemian subcultures flourish (Fischer 1975; Florida 2002; Lloyd 2002). Urban settings provide the necessary physical and social infrastructure where both musicians and confidence artists can find like-minded colleagues, available and flexible spaces for their performances, inexpensive and anonymous rehearsal areas, and willing audiences for their craft (Lloyd and Clark 2001).

By drawing on ethnographic research conducted in some of Chicago's most successful blues clubs, my goal is to illuminate the specific strategies of performance employed by producers attempting to pull off an event with as little apparent effort as possible. After describing my methodological approach, I explore three components of live music production qua confidence game: the cultural ecology of the con game and its participants, the strategies of deception and guile that make up the art of the hustle, and the particularities that help explain why confidence games often succeed. I then briefly explore how one group of participants-local blues

\footnotetext{
${ }^{3}$ Of course, it is hardly a secret that cultural producers that sell other types of commodified leisure and entertainment rely on the art of the con. Travel agencies make use of the "staged authenticity" of faraway tourist attractions to fool their most naive consumers (Boorstin 1961; MacCannell 1976). Restaurants mislead their customers by hiding the shortcuts or mistakes made during food preparation, whether by adding grill marks to baked steaks, masking the blemishes on desserts with whipped cream, or even bathing well-done roasts in red light to give off the impression of rareness (Fine 1996; also see Bourdain 2000). Food servers rely on emotion work to ingratiate their customers with contrived niceties (Hochschild 1983; Leidner 1993).
} 
musicians-reacts to their own experience of performing as confidence artists. Finally, I conclude by discussing the broader implications this work might suggest regarding other types of cultural production.

\section{RESEARCHING CHICAGO BLUES CLUBS}

The Chicago blues makes for a fitting case study of the resemblances between the traditional confidence game and the production of popular music. Blues music has always sold itself on the basis of its authenticity, particularly its attachment to certain regions of the country (Mississippi Delta, Chicago, Memphis, St. Louis), emotional states (love, desperation, loneliness), and black working-class settings. However, like other forms of popular music, the authenticity represented by the blues is a manufactured one, due in large part to the promotional efforts of cities like Chicago, and cultural myths that have endured for generations, from the bombastic legends surrounding cult heroes like Robert Johnson to the so-called racial purity of the early blues songs (Marcus 1975; Guralnick 1989; Davis 1995). According to Peterson (1997) record companies in the 1920s like Columbia designated their secular recordings by black musicians as "blues" in order to more efficiently market their black artists in a racially segregated society, even though many of those recordings were not stylistically different from their white "hillbilly" counterparts. This practice not only played a role in racializing the blues - in fact, it shaped an entire genre of music around purely imaginary conventions, regardless of singing style or lyrical content.

Given the historically manufactured nature of the blues genre, it is no wonder that the production of the Chicago blues is organized as if it were an elaborate confidence game in which performances and set pieces provide only the illusion of authenticity to paying consumers. I discovered this synthetic quality of the Chicago blues during a lengthy ethnographic study of several of the city's blues bars. I began my research during the winter months of 1998 at a local North Side blues bar appropriately (if unimaginatively) named B.L.U.E.S., where I conducted participant-observation as both a bar regular and an alto saxophone player. Through countless interviews and barroom conversations with audience members, musicians, bartenders and proprietors, I explored how producers and consumers collectively create the experience of the Chicago blues club. I supplemented this fieldwork with additional observations in thirty-six bluesoriented bars, nightclubs, restaurants and cafés located throughout the city. This expansion of the study brought me to places like the recently defunct Checkerboard Lounge, a well-worn tavern located in one of the city's historic South Side black districts, and a series of downtown tourist attractions such as Blue Chicago, Buddy Guy's Legends, and the Famous Dave's BBQ \& Blues franchise. (For a further elaboration of my methodological approach, see Grazian 2003.) 
In many ways, ethnographic endeavors themselves resemble confidence games. Participant-observation requires that researchers manufacture roles suitable for their field site. The success of the performance often hinges on an ethnographer's ability to persuade an audience of their innocent and selfless intentions while downplaying the professional rewards that academic research and publishing provides. (Indeed, few scholars ever acknowledge tenure as their purpose for writing a book or article.) Like their criminal counterparts, communities of ethnographers share common "tricks of the trade" ranging from surreptitious fieldnote writing to strategies for developing rapport with informants (Emerson, Fretz, and Shaw 1995; Lofland and Lofland 1995; Becker 1998). And finally, like the victims of con artists, the willingness among subjects to be studied sometimes hails from the pleasures of flattery and companionship, if not more base desires for fame and a fast buck.

\section{THE CULTURAL ECOLOGY OF THE CONFIDENCE GAME}

Hyperbole aside, it is crucial at this stage to remind the reader that while concertgoers may in fact feel "ripped off" or hustled by a disappointing performance (i.e., Kot 1998), live music productions, blues or otherwise, are not actual confidence games: the former are built entirely on hoaxes and false promises that leave their victims empty-handed, whereas even the patrons of lousy music enjoy an experience that meets a modicum of their overall expectations. ${ }^{4}$ However, live music events such as those held in blues bars do share several formal properties with that of the con, including a set of structural relationships that make up their respective cultural ecologies.

High-stakes confidence games generally involve five teams of participants: (1) operators, (2) ropers, (3) insiders, (4) shills, and (5) the mark, or victim. The operator typically funds the swindle, hires the necessary personnel for the job, and makes additional arrangements concerning the time and place of the con. The roper is responsible for identifying an easy mark, befriending them, and eventually luring them to the scene of the crime, where they will be introduced to the insider, who will ultimately put the mark "on the send," or convince him to procure a large sum of money to invest in what he thinks will be a low-risk gambling venture, a guaranteed bargain, or some other "sure thing" that will inevitably fall apart at the last minute. Once the mark is in the company of the roper and insider, a set of shills, or accomplices, perform the small but necessary role of "innocent" bystanders who encourage the mark to follow through on the deal. For instance,

\footnotetext{
${ }^{4}$ While the art worlds surrounding popular music scenes maintain a set of conventions regarding evaluative standards of performance (Becker 1982), these standards are often vague and rarely explicit (Gans [1974]1999; Kammen 1999; also see Klein 2003): For this reason, consumers must often resign themselves to the "caveat emptor" policies of music venues, even in situations in which their disappointment is shared by many audience members.
} 
during the production of a rigged betting game, a group of shills will sometimes play the role of seemingly sincere onlookers instructed to cheer on the players at the moment the mark arrives at the table, in the hopes that he will volunteer to play himself.

A similar set of relationship exists within the blues club, in which five sets of teams also actively participate: (1) club owners, (2) boosters, (3) musicians, (4) support personnel, and (5) leisure and business travelers. Very generally, leisure and business travelers seek out blues clubs in Chicago in order to participate in what they regard to be an authentic experience, and the remaining four teams of actors attempt to "con" these consumers by manufacturing authenticity for them in a manner that comes off as convincingly as possible. Relying on the cultural ecology of the confidence game outlined above, I characterize each of these participants as follows.

\section{Club Owners}

As the business entrepreneurs responsible for launching the city's blues clubs, as well as dictating their interior designs and hiring their musical talent and service staff, club owners resemble the operators of con games who finance the proposed operation which, in recent decades, has become far more elaborate than in the blues bars of yesteryear. During the late 1970s, most blues clubs were located in low-rent neighborhoods and run as shoestring operations lacking in organizational structure and long-term business plans. Rob Hecko, the owner of B.L.U.E.S., reflects on the informality of the club's profit-making enterprises:

There was no cover charge ... and we'd pass the troll around... Have you ever seen the troll? David, Bill Gilmore's lifelong friend, made it out of papier mâché, so we had this troll, a blue troll with a great big tail, and a great big hole in its head that you'd walk around and gather money for the band, and that's how we'd "pass the hat." The only days we had a cover charge was Friday and Saturday, for which we had a dollar cover charge...

However, during the mid-1980s clubs like B.L.U.E.S. began orienting themselves as commercial ventures, and relied on the enthusiasm of out-of-towners for much of their success. Again, according to Hecko:

Pretty much '84, '85-I would say it was pretty much then, 'cause that's pretty much when we starting forming the record company, which meant that we had been making too much money ... We had started developing much more of a convention crowd ... I think the longevity, and the Europeans realizing we were there... we were developing a reputation overseas ... the conventioneers, the tourists, the hotel concierges downtown realizing we were there ... I think that was the big hoop to get over... Also, at some point in time we were getting a lot of suburbanites... especially on the weekends.

Today, club owners operate establishments geared primarily toward attracting outof-towners, requiring close coordination with independent boosters, media and other promotional apparatuses, as well as the musicians and support personnel whom they hire directly. 


\title{
Boosters
}

Media outlets and other civic boosters operate as ropers in their attempts to lure music enthusiasts to local blues clubs. In the game of urban politics, newspapers, magazines, television stations and public relations firms serve as "auxiliary players" who routinely assist in generating public support for local businesses insofar as a city's economic growth often leads to increased profits and power for those organizations (Suttles 1984; Logan and Molotch 1987). By emphasizing Chicago's blues heritage and its self-proclaimed reputation as the "Home of the Blues," or "Blues Capital of the World," boosters try to market blues venues to potential consumers in countless newspaper articles and guidebooks to the city. In the following article from the black-owned Chicago Defender, journalistic copy serves as a thinly veiled advertisement for a local blues outfit:

During the great migration northward, African Americans brought their idioms with them and Chess Records later documented the many blues singers and instrumentalists, enabling Chicago to become a center for the blues... During the decades of the late '40s through the '60s, however, there developed the urban blues style and it flourished, particularly in Chicago. When the blues are performed at Mr. Ricky's, it promises to be a social travelogue in music of the African American experience in the big city (Calloway 1996).

This enthusiasm for Chicago's blues heritage is also shared by guidebooks oriented towards out-of-towners, rather than locals:

\begin{abstract}
In the early part of this century, as the steel mills of Gary and Hammond and East Chicago began smoking in earnest, Chicago began to attract its now-majority black population, many from the Mississippi Delta. It's a community that has contributed greatly to the city's special flavor ... and the creation of the urban electric blues by Muddy, Little Walter ... music that provided rock n' roll with its heartbeat... And the blues is still alive and well in Chicago (Bates 1989).
\end{abstract}

Although Chicago's blues legacy may appear to be self-evident, it is actually a recent invention. While the blues has always been important to members of the local black community, as demonstrated by the Defender article above, guidebooks to the city only began touting the city as the so-called "Home of the Blues" after white audiences began consuming blues music in large numbers during the late 1960s and early 1970s. Today, boosters continue to promote this reputation as a means of "roping" tourists and directing them toward local clubs and their entertainment districts.

\section{Musicians}

In con game lingo, the blues musician represents the insider, as he is responsible for receiving the mark once he or she has been directed to the club by the roper. As an insider, the musician must offer a credible performance that convinces the mark of the authenticity of his tourist experience. This performance often hinges 
on its adherence to a set of traditional if erroneous stereotypes concerning how blues performers ought to look and sound. Typically, this set of stereotypes is overwhelmingly based on race, as Elliot, a white guitarist, explains:

\begin{abstract}
It's because white audiences and owners are ignorant. The owners know that tourists will ask at the door, "Well, is the band playing tonight a black band, or is it a white band?" Because the tourists only want to hear black bands, because they want to see an authentic Chicago blues band, and they think a black band is more real, more authentic. When they come to Chicago, it's like they want to go to the "Disneyland of the Blues." You know, it's like this: People want German cars, French chefs, and, well, they want their blues men black. It's a designer label.
\end{abstract}

For this reason, most Chicago blues clubs employ black men exclusively. Just as the insiders of the classic confidence games appear affluent and sophisticated in order to best persuade the mark of their high social standing and virtuosity, most successful Chicago blues musicians are expected to comport themselves as working-class black men who have lived a life of hard labor (sometimes by hiding their middle-class backgrounds and college educations to their audiences) in order to provide evidence of their legitimacy as keepers of the blues tradition.

\title{
Support Personnel
}

Becker (1982) argues that support personnel represent the network of producers necessary for the creation and dissemination of artistic and cultural works and events, and include oft-forgotten yet essential contributors to this process, such as trumpet manufacturers or set designers. In Chicago blues clubs, workers such as bouncers, bartenders and table servers operate as a set of shills or accomplices who assist the musicians in generating an aura of authenticity and enthusiasm for patrons to consume.

These confederates participate largely by performing the role of the ecstatic participant, ready to persuade audiences by example that they should be having a ball as well. The bouncer's regular announcement between sets encourages patrons to join in on the fun: "Hey-hey, please put your hands together for the band!! Right now, the band's gonna take a brief pause for a worthy cause, but don't go anywhere, because the band will be right back for two more sets!" According to Suzanne, a waitress at B.L.U.E.S., "Of course, when you work at this job you have to put on a smile for the customers, because that's part of your job." Meanwhile, the emotional labor required of servers includes handling rude and suggestive comments from drunk male patrons with polite grace and aplomb, laughing at jokes that are not particularly funny, and fervently clapping to the music in time while working behind the bar. Just as overexcited shills add to the "atmosphere of synthetic excitement" during the climaxes of three-card monte games and other cons (Maurer [1940]1999, p. 47), blues club owners employ support personnel in part to help artificially heighten the overall mood experienced by their patrons. 


\section{Leisure and Business Travelers}

Since the mid-1980s, Chicago blues clubs have relied on the rise of tourism and convention traffic in the city as a means of increasing their patronage. Blues fans come to Chicago from all over the world, from nations as varied as Algeria, Poland, Spain, Great Britain, Germany, Brazil and Japan, to seek out the authenticity supposedly represented by its music scenes. These patrons seem to attribute a magical power to these clubs, as exemplified by Skya, a young student from Poland:

\footnotetext{
The one thing I love the most about Chicago...It's the blues. I love it! .. . Tonight, this is my first time hearing blues in Chicago ... I've always wanted to go, because the best place for blues is in Chicago, the blues originated in Chicago, and so I've always wanted to go, and tonight I finally got to come... It's probably the most important thing I've done since I've been here. It's amazing... Oh, it is the best, I love it! ... In Krakow in the south of Poland, we have a blues club, and I've been to it, but it is nothing compared to this ... no, this is the best.
}

The traveler represents the mark, or intended victim. While blues clubs attract more savvy locals and bar regulars as well as out-of-towners, the latter make the most suitable marks, as their unfamiliarity with local surroundings makes them much more susceptible to being "duped." As David W. Maurer ([1940]1999, p. 33) argues in his classic expose The Big Con: The Story of the Confidence Man, "the mark must not be a resident of the city where he is to be trimmed," and the reasons for this will be made clearer in the next section.

\section{THE ART OF THE CON}

Goffman (1959) explains that our social lives are most successfully performed on "front stages" that have been designed specifically for the purpose of impressing others. We tidy up our houses before important guests arrive; join faculty clubs that feature sitting rooms adorned with exquisite furnishings; and rent out expensive hotel ballrooms for weddings and anniversary parties. The physical settings of our performances operate like stage sets, and they work best when we have a degree of control over them.

Similarly, in The Big Con Maurer describes the most important tool used by the successful confidence artist: the "big store." The big store is a room or set of rooms designed to look like a place of business, gambling casino, bank or any other space required by the con. In a classic confidence game called the "wire," operators rent out a room and redesign its interior as an exclusive off-track betting parlor where victims are brought by a roper who convince them to wager large sums on sure things that inevitably go sour at the last minute. While marks often discover that the roper is a con artist, they rarely catch on that the parlor itself is fake, and that the con lies in the manipulation of their immediate surroundings as much as their hearts and minds.

Chicago blues club owners fabricate the interiors of their businesses in a similar fashion. Through racially charged myths perpetuated in films and other 
narratives of fantasy, three contrasting images represent the stereotypical blues club: the barbeque, the den and the dump. Just as operators employ the "big store" as a strategy of deception, club owners manufacture each of these permutations of the romanticized blues club in order to lull their patrons into imagining that they have entered a truly authentic zone of experience.

For instance, during the 1930s and 1940s in Chicago's Black Belt blues players would perform jump blues and piano boogie-woogie in crowded apartments where tenants would throw late-night parties, often in order to raise enough money to pay that month's rent. At these rollicking parties, guests were typically served home-cooked meals taken from Southern recipes, and many contemporary blues bars attempt to reproduce the atmosphere of the barbeque by plying their predominantly well-heeled customers with a culinary orgy of Mississippi Delta-bred soul food: smoked brisket and baby back ribs, fried okra and collard greens, and puddles of hickory-smoked sauce. At Buddy Guy's Legends, menu highlights include the Soul Combo, Bubba's Jumbo Gumbo, and the Big Bayou Blue Plate Special. Meanwhile, at the former Famous Dave's BBQ \& Blues franchise, affluent audiences devoured Fire-Kissed Mojo Chicken and Sweet Georgia Mama's Chopped Pork served on a garbage can lid.

Similarly, dens represent stylish and seemingly old-fashioned juke joints and nightclubs. Like Buddy Guy's Legends their physical interiors recall comparably familiar stereotypes of black culture and authenticity. At Blue Chicago, photographic prints of African American revelers cover the club's walls along with paintings featuring caricatures of bellowing blues women and Rabelaisian party scenes. On the club's exterior, a large mural depicts a black guitarist with a cigarette dangling from his lips and a bottle of booze at his side. In its efforts to market these images to tourists, the club's white owner sells T-shirts depicting such renderings for $\$ 18$ each, along with specially made soundtrack recordings produced by the club. Smoke Daddy, another local club, suggests an equally playful blues hideaway with its bright neon sign, multicolored Christmas lights and 1950s-style dining booths. In painstakingly retro fashion, the club's walls showcase provocative photographs of black movie stars and rhythm-and-blues artists from the same period.

But perhaps the most cynical of the "big stores" intended to attract blues fans are designed as dumps: In keeping with Hollywood expectations of the authentic urban blues experience, these dilapidated bars are dimly lit, smoke-filled, ramshackle and rustic. At B.L.U.E.S., worn barstools line the plaster walls and splintering wood fixtures adorned with exposed nail heads - a trait that might seem less strange if the club were not located in Lincoln Park, one of the most affluent neighborhoods in Chicago. ${ }^{5}$ As it happens, B.L.U.E.S. entices customers

\footnotetext{
${ }^{5}$ This is not to suggest that unkempt properties do not exist within well-to-do neighborhoods. However, it is instructive to note that while its proprietors maintained the ramshackle state of B.L.U.E.S., they simultaneously poured funds into the upkeep of a second bar (named B.L.U.E.S. Etc.) known for its more upscale atmosphere.
} 
who flock to the club in taxicabs with the thrilling belief that the crumbling bar might serve as a more authentic rival to its upscale downtown counterparts, like Blue Chicago. Like the victims of more traditional confidence games (Maurer [1940]1999, p. 33), out-of-towners unfamiliar with the city are easily convinced of the staging of its urban environment.

If proprietors manufacture the authenticity of their clubs' overall look and taste, musicians also rely on a number of strategies of deception shared within their own tightly knit community of partners in crime. ${ }^{6}$ First, nearly all Chicago blues musicians rely on the same predetermined set list of songs to impress their audiences. Although the blues tradition includes hundreds of original compositions, musicians tend to repeat the same ten songs night after night, as they are market-tested crowd pleasers. These songs include well-known blues and rhythmand-blues hits: (1) "Sweet Home Chicago," (2) "I'm Your Hoochie Coochie Man," (3) "Got My Mojo Working," (5) "The Thrill is Gone," (6) "Johnny B. Goode," (7) Mustang Sally," (8) "Soul Man," (9) "Crosscut Saw," and (10) "Call It Stormy Monday." Daniel, a local guitarist and bandleader, explains:

\begin{abstract}
What happens on Friday and Saturday night when it's like, you know, packed full of tourists who really don't know anything? .. Y You know, they want to hear, I mean, I can just list for you the "set list from hell": "Every Day I Have the Blues," "Sweet Home Chicago," "Mustang Sally"... and, you know, those other fucking songs, you know, "Kansas City," and fuckin', you know, "Johnny B. Goode" and shit. You know, how are you supposed to play those songs for ten years, twenty years? .. But that is what these people wanna hear! Like, go to B.L.U.E.S. or Kingston Mines, or wherever ... The two blues songs everybody knows are "The Thrill is Gone" and "Sweet Home Chicago." And what does everybody sing along to? "Mustang Sally."
\end{abstract}

One of the reasons this "set list from hell" is so effective is that many of these songs are easily familiar to mainstream audiences unversed in the lesser-known traditions of the blues form. It also succeeds because audience members from out of town are unlikely to attend repeat performances, and are thus prevented from realizing they are hearing a prescribed list of proven standards routinely played night after night, rather than a selection of favorite songs personally chosen by the singer. ${ }^{8}$

In addition to this predetermined set list, the bag of tricks wielded by musicians also includes a set of politically incorrect jokes about oral sex, gay men and overweight women, all sprinkled among greatest hits medleys featuring random

\footnotetext{
${ }^{6}$ On the colleagueship of pool hustlers, see Polsky (1969, pp. 59-67).

${ }^{7}$ The boredom and near nausea reported by many blues musicians who play the same set of familiar standards during their performances appear to be a common problem among all different kinds of musicians, including jazz musicians (Becker 1963) as well as classically trained orchestral players (Faulkner 1971).

${ }^{8}$ As Goffman (1959, p. 49) argues, audience segregation offers performers the ability to "foster the impression that their current performance of their routine and their relationship to their current audience have something special and unique about them."
} 
samples of choice song lyrics, solos, rhythms and refrains. Farrell, a bass guitarist, recalls the onstage prowess of Son Seals, his former bandleader:

I played with Son Seals for about a year and a half, just up until somebody shot him in the face... Now, he always did the same set, and always used the same jokes, the same lines, but he was so good at it. Somehow, he learned how to push all the right buttons on the crowd, and they just loved every minute of it - in fact, I can only remember one time that he didn't get a reaction from the audience. But for him, it was all about finding those buttons and knowing just how and when to push them.

In part, these sorts of tricks work so well because, like the victims of con artists, audiences are not so much persuaded by the specific content of these performances, but by the manner in which they are presented (Maurer [1940]1999, pp. 36-37). While onstage, local black musicians accomplish this by appropriating racial and sexual stock characters reminiscent of nineteenth-century black minstrelsy (see Lott 1993), 1970s “blaxploitation" films, and 1990s gangsta-rap videos in exchange for abundant laughter and applause from their predominantly white audiences. Adorned in athletic apparel, Tiger, a youthful blues singer and guitarist, boasts of being a "candy-licking" man as he sings, "Open up your candy bars baby/Show me all you got/Once I start licking baby/You won't want my tongue to stop!" He baits the crowd by selecting female patrons to ask, "Is your man a candy-licking man?" "What kind of candy-licker is he?" Others tease their female audience members with innuendo rich in hyper-masculine bravado, sexual come-ons, and X-rated versions of otherwise banal songs such as "Hold On, I'm Comin"” and "She'll Be Comin' Round the Mountain When She Comes."

Elderly musicians play a slightly different set of roles. Billy, a black blues singer, shares his origins as a country bumpkin from Holly Springs, Mississippi and "confesses" his passions for "blues, barbecue, watermelon, and pretty girls." Dizzy, a 70-year-old black singer, appropriates a stage persona that emphasizes the worldweary desperation of the mythical songster. In his sunglasses and sharp feathered hat, he sighs: "I wouldn't have no luck at all if it weren't for bad luck... My old lady threw me out, my dog died ..." "I've been abused and misused . . . I feel so bad, I could shout." Later, Dizzy counters this pose with a snappier style as he shakes his way toward the stage, opens his arms wide and announces: "I have more fun than poor people is supposed to have .. . I could even have fun in a graveyard!"

Other performers affect a more saintly pose, as demonstrated by singer Tommy McCracken when he routinely delivers the following sermon from the stage at B.L.U.E.S.:

It's still Sunday, right? All right, I've got some things that I'll need to wait 'til after Sunday to say...But you know, the branch never falls too far from the tree... and I believe...I believe that if I had some water, if I was standing by the water, well then, do you know what I'd do?... Well, I'd pull up my pants, I'd roll up my pants real high, yes, I would...And I'd wade in the water...Yes, I'd wade, I'd wade ... I'd wade in the water, oh, Lord.

Here, McCracken draws on the authenticity associated with black church culture as well as the emotive intensity often associated with the blues, an intensity 
that comes off as genuine even though he recites the same speech during all of his performances. ${ }^{9}$ Meanwhile, before his passing in 1998, James Ramsey, a popular local character dubbed the "Black Lone Ranger," strolled around the Checkerboard Lounge (a recently shut-down blues bar which was located in Bronzeville, one of the city's historic black neighborhoods) selling home-recorded tapes featuring his renditions of blues standards such as "I'm a Man," and invited customers to pay to have their instant photograph taken with him in his theatrical regalia, replete with white ten-gallon hat and black mask.

This last example not only demonstrates the racially charged nature of blues performances both onstage and off, but also illuminates the importance of getting audience members to actively participate in the performance itself, particularly if they are to be convinced that they have gotten their money's worth. In con games, the mark is willing to trust his swindlers because they seem to place so much confidence in him. Sometimes, con artists accomplish this feat by making the mark feel like they are contributing toward pulling off a con themselves (directed against someone else, of course) by making him privy to "private" passwords, "secret" codes, and a set of seemingly clandestine operations in which they are to be utilized.

For their part, the musicians' deployment of the overwhelmingly familiar songs that make up the "set list from hell" makes patrons feel as though they are sufficiently "in the know," as do opportunities that allow for a wide degree of audience participation. One singer invokes the call-and-response indicative of black church culture to arouse customers as they repeat after him, "C-H-I-C-A-G-O!" while another performer passes around a microphone to courageous patrons who growl out their best renditions of well-known blues lyrics: "Got my mojo working!" "Ride, Sally, ride!" 10 When performers introduce "Sweet Home Chicago," the city's easiest crowd pleaser, it is never difficult for them to cajole their audiences into singing aloud in unison to the familiar chorus: "Come on, baby, don't you want to go? Back to that same old place-Sweet Home Chicago?" Other musicians invite their most enthusiastic patrons to join them onstage for a dance, a kiss, and occasional sexual contact (see Grazian 2003, pp. 49-50). By incorporating the audience into the actual performance, blues musicians flatter their audiences by making them feel more involved and knowledgeable about the blues than they actually are, and this helps further distract consumers from the meticulously scripted performance of authenticity sold within the commercialized blues club. ${ }^{11}$

\footnotetext{
${ }^{9}$ According to Pattillo-McCoy (1998), practices borrowed from black church culture are often used in secular settings to encourage social solidarity and incite collective action. For discussions of its uses in popular music performance as a symbol and strategy, see Baraka (1963); Keil (1966); Gilroy (1991).

${ }^{10}$ For a discussion of the uses of call-and-response styles in black church culture, see Hamilton (1972, pp. 28-32); Levine (1977).

${ }^{11}$ This performance extends to the offstage yet public remarks made by musicians, which audience members relish because they incorrectly imagine that these "private" moments exist outside of what Goffman (1974) refers to as the "theatrical frame."
} 


\section{WHY THE CONFIDENCE GAME SUCCEEDS}

Contemporary blues clubs operate in a similar fashion to traditional confidence games in part because each maintains an analogous cultural ecology of participants along with their respective strategies of action. Thus, it is hardly surprising that each also relies on a similar set of conditions for its success: (1) the moral and financial motivations of the producers of the operation; (2) the willingness of the state to assist in the enterprise; and (3) the desire among victims themselves to be swayed by the production at hand.

First, in both instances the perpetrators have a compelling moral as well as financial interest in success. In Polsky's (1969, p. 81) account of pool playing, sharks prefer their so-called deviant careers to more normative jobs because they find hustling more fun, exciting, and even "heroic" (also see Goffman 1967; Katz 1988). Likewise, musicians gain a satisfying thrill from pulling off a successful and effective performance that truly moves the audience. According to Daniel, the aforementioned musician who coined the phrase "set list from hell": "I enjoy having to win an audience over, no matter who they are, and I can look at an audience and see what I have to do and try to do that. I mean, that's the total challenge...I'm into that shit, you know, that's what it's all about..."

Of course, musicians also take this challenge seriously because their financial success depends on it as well. As Tiger remarks:

I love the audience, 'cause I'll get to them sooner or later. And when I'm a sideman, I play what the leader wants me to play, I'll do whatever they want, and I'll do it the best that I can, and get paid. Of course, I'll try to add something to it ... and it doesn't matter for me, because I'll get to them, regardless.

Like con artists, for some musicians pleasure and profit are one and the same goal. As Dizzy, an elderly blues singer, howls one evening at B.L.U.E.S. after I ask him whether he has been having fun after one of his shows: "Having fun? Shit, man ... It's not about havin' fun. It's about makin' money-now that's what it's all about! Havin' fun? Naw, making money, man, that's what $I^{\prime} m$ talking about ... Hell, then you can go out and buy your own fun! Ha ha!"

Secondly, in addition to these motivating factors the state often plays a deciding role in the success of both enterprises as well. According to Maurer ([1940]1999, pp. 214-247), big cons require protection from a "fixer" who pays off police officers, prosecutors, judges and other political figures in exchange for their acquiescence and occasional assistance in fleecing out-of-town victims. ${ }^{12}$ In the case of the Chicago blues, the arrangement that exists between the blues club and the state differs from the con only in that local political organizations are so actively involved in tightening up the mark - and subsequently profiting from the

\footnotetext{
${ }^{12}$ According to con lingo, the fixer is also referred to as "tin-mittens," a confederate who "likes to hear the coin clank in his hand" (Maurer [1940]1999, p. 308).
} 
success of local blues bars - that they do not even require bribes or payoffs from club operators. According to Barry Dolins, the coordinator of the annual Chicago Blues Festival and the deputy director of the Mayor's Office of Special Events, the city has a financial incentive to promote its blues heritage insofar as it helps increase tourism and, by extension, revenue for the local economy:

The Blues Fest is one of many enterprises which markets the city to visitors... We have moved from a city of manufacturing to a service-based city where tourism has become increasingly important, where catering to leisure travelers is as important to the city as big business ... The festival helps to foster an image of Chicago as a world-class city ...

For this reason, the city of Chicago invests a great deal of capital to promote itself as the so-called "Home of the Blues" through its tourism campaigns, cultural programming and music festivals. These campaigns include city-subsidized bus tours to South Side blues clubs and the former blues recording studios of Chess Records; public celebrations held in honor of local blues legends such as Muddy Waters; and the aforementioned Chicago Blues Festival, which in 1998 attracted an estimated 660,000 fans for the four-day event (Kot 1998).

By marketing the city's blues clubs as venues in which to consume authentic blues music, the state operates as a not-so-silent partner in assisting such clubs in carrying out their performances, subsequently pocketing a share of the resultant cash flow directly through a set of consumption taxes. ${ }^{13}$ Through their promotional efforts and a strong financial incentive of their own, public authorities and other urban elites attempt to reconfigure the entire city itself as a "big store" designed to draw out-of-towners to Chicago where they can be subsequently enticed to spend money in local establishments. In fact, in some ways the city operates as a roper as well as a fixer, insofar as its promotional machine, in concert with local media and other booster organizations, directs potential audience members first to Chicago, and then to the blues clubs where they will be confronted by the performances of musicians and their accomplices.

Finally, it is instructive to note that confidence games typically victimize those who are most easily persuaded to follow their own inner con artist, gambling their fortunes at a chance for a big score. Once again, according to Maurer ([1940]1999, pp. 116-117):

The first thing a mark needs is money. But he must also have what grifters term "larceny in his veins"-in other words, he must want something for nothing, or be willing to participate in an unscrupulous deal. If a man with money has this trait, he is all that any con man could wish. He is a mark. "Larceny," or thieves' blood, runs not only in the veins of professional thieves; it would appear that humanity at large has just a dash of it-and sometimes more. And the con man has learned that he can exploit this human trait to his own ends; if he builds it up carefully and expertly, it flares from simple latent dishonesty to an

\footnotetext{
${ }^{13}$ From a financial point of view, the city benefits indirectly as well, insofar as entertainment serves as a dominant engine of local economic growth for the city (Lloyd and Clark 2001). On the linkages between urban cultural movements and the political and economic landscapes of urban areas, see also Zukin (1982, 1991, 1995); Suttles (1984); Logan and Molotch (1987).
} 
all-consuming lust which drives the victim to secure funds for speculation by any means at his command. ${ }^{14}$

Do the patrons of blues clubs similarly possess this "larceny" in their veins? While generally well intentioned, many blues fans do display a similar sense of greed, but not for money as much as for authenticity, a cultural value symbolized in this context by the coarsest stereotypes of race and class, as I have demonstrated. This deep-seated desire bears itself in the questions that white middle-class patrons have asked me upon arrival at the Checkerboard Lounge, the aforementioned South Side bar: "So, would you call this club more authentic? Is the music more authentic?" The gritty interior of the club, as revealed by its ripped seats, tables lined with fading contact paper, and restroom floors carpeted with flattened cardboard boxes, appeals to visitors in search of the rugged authenticity they attach to its helter-skelter atmospherics. In comparing the Checkerboard to an uptown jazz haunt known for its decidedly more upscale interior, Rajiv, a conventioneer, gushes with pleasure, "The Green Mill was very polished; I like this place a lot moreespecially the décor."

For consumers, the ability to procure and consume authentic cultural products signifies a certain degree of self-confidence as well as cultural capital—or, perhaps in this instance, subcultural capital (Thornton 1996; also see Bourdieu 1984; Peterson 1992; Lamont and Fournier 1992), as these middle-class consumers recreate themselves in the same urbane, hip and decidedly authentic image they project onto the local blues club. And as these patrons respond gleefully with delight to the racially charged signifiers existing within the commercialized blues club-the Black Lone Ranger, the Candy-Licking Man, Sweet Georgia Mama's Chopped Pork served on a garbage can lid-club owners and musicians are further reminded that their performance of authenticity fools the mark, and they become all too eager to repeat the show all over again, with the same crowd pleasers, the same dirty jokes, and the same tricks of the trade.

\section{LIVING THE LIFE}

Of course, the success of the confidence game presents a set of inconveniences for the swindler as well as swindled. Trustworthiness among thieves represents a common occupational hazard for any quasi-criminal pursuit, and sometimes the ropers and insiders get less of the take than the significantly more powerful operators who employ them, and their fixers who keep them out of jail. Similarly, while many blues musicians report that their jobs give them great satisfaction, the intense commercial forces of the Chicago blues that give rise to the strategies of deception commonly practiced in local clubs frustrate them as well—financially, artistically

\footnotetext{
${ }^{14}$ In a discussion on relations of trust, Coleman (1990, pp. 104-106) similarly argues that the victims of confidence games frequently decide to participate in such deals after rationally calculating the amount of the potential payoff they would stand to gain from the hustler's offer, relative to the potential loss.
} 
and morally. First, musicians complain about the lack of monetary compensation afforded them in times of plenty. According to Louis, a black saxophonist and bandleader:

Well, it's true ... the blues scene in Chicago has become more commercial ... Today, people who have money are spending it on blues, and so it has become very profitable. Musicians have had nothing to do with that-blues has just become profitable, and in fact while musicians are making a little more money, those profits have mostly gone to club owners, record companies, and other people.

While Louis would presumably want to reap greater financial rewards for his onstage efforts, he exhibits an even greater frustration over how the imperative to pander to audiences through predetermined set lists and the like prevents him from expressing himself as a truly creative and autonomous artist:

Today, the quality of the music is not the bottom line at these clubs ... bringing in money, that's the bottom line. I mean, it don't matter who you are... If you're a garage band, and you can bring people in the club and make them money, you'll be hired. You in this to make money. Now, when I first started out, I initially did it for the love of the money. But now, I want to do my own thing, I want to be that band that when people come to hear you, they know you're doing something original, something that's all your own...

Ultimately, taking on the role of the authentic blues musician prevents Louis from playing a much more familiar character: himself. Tiger, the aforementioned blues singer, blames his employers, the club owners, for maintaining control over how musicians perform for their patrons:

I don't like a lot of the bands they got playing at the Kingston Mines ... Over there, those acts, like Betty Johnson, they're not really singing what they feel... They're just doing it for the audience - doing the same old thing, you know? When I hear a band, I want some variety; I want to see something new. But it's the owners, see? They tell these bands what to play, what to wear...even what kind of hat to wear. And after playing the same tunes, you get tired... . but even I know you have to play them.

The strategic tactics deployed by club owners regarding musicians' play lists and apparel extend to hiring decisions made on the basis of racial difference, and this practice frustrates black musicians as much as whites, particularly those whose bands have trouble procuring gigs because their colleagues happen to be white and might therefore disrupt the synthetic aura of authenticity manufactured in local blues venues. According to Shawn, a black bass player:

I've always been treated OK, but a lot of times the owners will try to break up your band if you have too many white guys. Like, if a band has three black guys, the owners sometimes let them have two white guys, but a lot of times they'll say there's too many white guys on the stage, because, well, you know, the blues is supposed to be the music of blacks, and they're doing it for the tourists, and it's all about business.

But if you can play the blues, it doesn't matter who you are-anyone can play the blues. It doesn't take a certain kind of person to play the blues ... Everybody gets the blues, right? So, either you can play the blues or you can't, and it doesn't matter if you're white or black or whatever... But the owners, they'll try to break up your band if you've got too many whites. 
As these musicians reflect on the manufactured authenticity of the Chicago blues club, it becomes clear that their success may be bittersweet insofar as they also fall victim to the merciless logic of the confidence game and its cultural ecology, just as their marks do.

\section{DISCUSSION AND CONCLUSION}

In the end, the cultural ecology of the confidence game comes full circle. Club owners finance the operation and pay musicians to work as insiders within the walls of the blues club, the "big store." Political authorities serve two functions: first as ropes, directing the mark to the club, and then as fixes, colluding with club owners in order to increase the city's flow of economic and tax revenue. Bartenders and servers work as support personnel, confederates who add to the emotional intensity inhabiting local blues clubs. For their part, leisure and business travelers serve as willing marks, arriving at the big store, paying their money, and experiencing an evening of entertainment valued for its authenticity, when in fact the entire affair has been manufactured for their benefit. Eventually, everyone else gets paid, and the whole routine starts up again the following evening.

The success of the Chicago blues club lies in its ability to stage an authenticity that does not actually have a counterpart in the material world — only the fantasy is real-and clearly this observation could be extended to other situations in which popular music is produced for a live audience. Despite the grittiness of seedy urban punk clubs, rock bands and their fans frequently hail from middle- and upperclass backgrounds (Frith 1981), and the bars they inhabit often remain unkempt and graffiti-strewn long after they become profitable. Similarly, the hard-edged "ghetto" sounds of hip-hop rappers and DJs frequently emanate from the turntables of suburban black youth, just as the "cowboys" who sing in country western bars for a living may not actually rope calves and bale hay to make ends meet on the family farm (see Peterson 1997). Additionally, the music performed in tourist attractions like Chicago blues clubs may express this phenomenon better than any other, particularly since tourism is often structured around the consumption of authenticated cultural sites (MacCannell 1976; Cohen 1988). In Rome, street musicians wander through public piazzas, treating diners to Italian music lovingly performed on traditional instruments - although it is difficult to imagine how any audience would fall for the Roman "set list from hell," which, as far as I could gather from my last visit, includes "That's Amore" and the orchestral score from the film The Godfather. The point here is not to suggest that these artists are any less talented or deserving than anyone else, but only that a strategy of misrepresentation is sometimes unavoidable if one is to perform authenticity in the context of live music production.

In the end, perhaps this strategy works so effectively because all of the actors involved — club proprietors, boosters, musicians, support personnel and, most of 
all, the audience — possess not only a financial stake in the credibility of their performances, but a personal one as well. One of the reasons why musical performances sometimes succeed in spite of themselves is that audiences desperately want to be entertained, and will therefore forgive any number of inconsistencies or obvious gaffes made during the performance of authenticity in order to enjoy themselves. Ultimately, this desire explains why the blues club operates so effectively as a confidence game, as well as why Roman audiences often shower their Italian hosts with tips upon hearing "That's Amore"-because the alternative would be disappointment and slight embarrassment with the whole affair.

For this reason, it remains unclear who emerges as the true victim of popular music productions. After all, musical performances typically fulfill their audiences on at least some level, while their lack of knowledge regarding the manufactured aspects of live shows seems like more of a blessing than anything else. However, the same cannot be said of musicians, for they are all too aware of the strategies of deception maintained onstage. As previous work in the sociology of music demonstrates, a lifetime of performing any "set list from hell" takes its toll on all different kinds of musicians, whether they are jazz sidemen forced to play "Beer Barrel Polka" at weddings (Becker 1963, p. 94), or orchestral instrumentalists resigned to perform Brahams in $\mathrm{C}$ minor for equally demanding audiences (Faulkner 1971, p. 71). For those musicians, the con may actually be on them.

\section{ACKNOWLEDGMENTS}

I would like to thank Garth Bond, Meredith Broussard, Jason Schnittker, and the editors and anonymous reviewers of Qualitative Sociology for their helpful suggestions on an earlier version of this article.

\section{REFERENCES}

Abbott, A. (1997). Of time and space: The contemporary relevance of the Chicago school. Social Forces, 75, 1149-1182.

Anderson, B. (1991). Imagined communities: Reflections on the origin and spread of nationalism. London: Verso.

Azerrad, M. (2001). Our band could be your life: Scenes from the American indie underground, 19811991. Boston: Little, Brown.

Baraka, A., as Jones, L. (1963). Blues people: Negro music in white America. New York: William and Morrow.

Bates, C. D. (Ed.). (1989). The best of Chicago. New York: Prentice Hall.

Becker, H. S. (1963). Outsiders: Studies in the sociology of deviance. Glencoe: Free Press.

Becker, H. S. (1982). Art worlds. Berkeley: University of California Press.

Becker, H. S. (1998). Tricks of the trade. Chicago: University of Chicago Press.

Boorstin, D. J. (1961). The image: A guide to pseudo-events in America. New York: Vintage.

Bosk, C. L. (1979). Forgive and remember: Managing medical failure. Chicago: University of Chicago Press.

Bourdain, A. (2000). Kitchen confidential: Adventures in the culinary underbelly. New York: Bloomsbury. 
Bourdieu, P. (1984). Distinction: A social critique of the judgment of taste. Cambridge: Harvard University Press.

Calloway, E. (1996). Mr. Ricky's hosts blues blowout. Chicago Defender, May 14, p. 16.

Cantwell, R. (1996). When we were good. Chicago: University of Chicago Press.

Cohen, E. (1988). Authenticity and commoditization in tourism. Annals of Tourism Research, 15, 371-386.

Coleman, J. S. (1990). Foundations of social theory. Cambridge: Harvard University Press.

Cornwell, B., Curry, T. J., \& Schwirian, K. P. (2003). Revisiting Norton Long's ecology of games: A network approach. City and Community, 2, 121-142.

Cressey, P. G. (1932). The taxi-dance hall. Chicago: University of Chicago Press.

Davis, F. (1995). The history of the blues. New York: Hyperion.

DiMaggio, P. (1987). Classification in art. American Sociological Review, 52, 440-455.

Emerson, R. M., Fretz, R. I., \& Shaw, L. L. (1995). Writing ethnographic fieldnotes. Chicago: University of Chicago Press.

Faulkner, R. R. (1971). Hollywood studio musicians. Chicago: Aldine Publishing.

Fine, G. A. (1996). Kitchens: The culture of restaurant work. Berkeley: University of California Press.

Fischer, C. (1975). Toward a subcultural theory of urbanism. American Journal of Sociology, 80, 1319-1341.

Florida, R. (2002). The rise of the creative class. New York: Basic Books.

Frank, T. (1997). Alternative to what? In T. Frank \& M. Weiland (Eds.), Commodify your dissent: Salvos from the Baffler. New York: Norton.

Frith, S. (1981). Sound effects: Youth, leisure, and the politics of rock ' $n$ ' roll. New York: Pantheon.

Fruehwald, S. (1988). Authenticity problems in Joseph Haydn's early instrumental works: A stylistic investigation. New York: Pendragon.

Gans, H. J. ([1974]1999). Popular culture and high culture: An analysis and evaluation of taste. New York: Basic Books.

Gilroy, P. (1991). "There ain't no black in the Union Jack”: The cultural politics of race and nation. Chicago: University of Chicago Press.

Goffman, E. (1959). The presentation of self in everyday life. Garden City, NY: Anchor.

Goffman, E. (1967). Where the action is. In Interaction ritual: Essays on face-to-face behavior. New York: Pantheon.

Goffman, E. (1969). Strategic interaction. Philadelphia: University of Pennsylvania Press.

Goffman, E. (1974). Frame analysis: An essay on the organization of experience. Boston: Northeastern University Press.

Grazian, D. (2003). Blue Chicago: The search for authenticity in urban blues clubs. Chicago: University of Chicago Press.

Guralnick, P. (1989). Searching for Robert Johnson. New York: Dutton.

Hamilton, C. V. (1972). The black preacher in America. New York: William Morrow.

Hobsbawm, E., \& Ranger, T. (Eds.). (1983). The invention of tradition. Cambridge, UK: Cambridge University Press.

Hochschild, A. R. (1983). The managed heart. Berkeley: University of California Press.

Hughes, E. C. (1958). Men and their work. London: Free Press of Glencoe.

Kammen, M. (1999). American culture, American tastes: Social change and the 20th century. New York: Knopf.

Katz, J. (1988). Seductions of crime: Moral and sensual attractions in doing evil. New York: Basic Books.

Keil, C. (1966). Urban blues. Chicago: University of Chicago.

Kenyon, N. (1988). Authenticity and early music: A symposium. Oxford: Oxford University Press.

Kivy, P. (1995). Authenticities: Philosophical reflections on musical performance. Ithaca, NY: Cornell University Press.

Klein, B. (2003). Dancing about architecture: Popular music criticism and the negotiation of authority. Unpublished MA thesis, Annenberg School for Communication, University of Pennsylvania.

Klinenberg, E. (2002). Heat wave: A social autopsy of disaster in Chicago. Chicago: University of Chicago Press.

Kot, G. (1998). Blues tease. Chicago Tribune, June 6, sec. 1, p. 2. 
Kot, G. (1998). Fest overcomes poor start, cool weather and a variety of competition. Chicago Tribune, June 8 , sec. 5 , pp. $1,4$.

Lamont, M., \& Fournier, M. (Eds.). (1992). Cultivating differences: Symbolic boundaries and the making of inequality. Chicago: University of Chicago Press.

Leidner, R. (1993). Fast food, fast talk: Service work and the routinization of everyday life. Berkeley: University of California Press.

Leppard, R. (1988). Authenticity in music. London: Faber Music.

Levine, L. (1977). Black culture and black consciousness: Afro-American thought from slavery to freedom. Oxford: Oxford University Press.

Lloyd, R. (2002). Neo-bohemia: Art and neighborhood redevelopment in Chicago. Journal of Urban Affairs, 24, 517-532.

Lloyd, R., \& Clark, T. N. (2001). The city as an entertainment machine. Critical Perspectives on Urban Redevelopment, 6, 359-380.

Lofland, J., \& Lofland, L. H. (1995). Analyzing social settings: A guide to qualitative observation and analysis (3rd ed.). Belmont, CA: Wadsworth.

Logan, J. R., \& Molotch, H. L. (1987). Urban fortunes: The political economy of place. Berkeley: University of California Press.

Long, N. E. (1958). The local community as an ecology of games. American Journal of Sociology, 64, 251-261.

Lott, E. (1993). Love and theft: Blackface minstrelsy and the American working class. New York: Oxford University Press.

MacCannell, D. (1976). The tourist: A new theory of the leisure class. New York: Schocken.

Marcus, G. (1975). Mystery train: Images of America in rock 'n' roll music. New York: Plume.

Marcus, G. (2001). The old, weird America: The world of Bob Dylan's basement tapes. New York: Henry Holt.

Maurer, D. W. ([1940]1999). The big con: The story of the confidence man. New York: Anchor.

McLeod, K. (1999). Authenticity within hip-hop and other cultures threatened with assimilation. Journal of Communication, 49, 134-150.

Padgett, J. F. (1985). The emergent organization of plea bargaining. American Journal of Sociology, $90,753-800$.

Padgett, J. F., \& Ansell, C. K. (1993). Robust action and the rise of the Medici, 1400-1434. American Journal of Sociology, 98, 1259-1319.

Pattillo-McCoy, M. (1998). Church culture as a strategy of action in the black community. American Sociological Review, 63, 767-784.

Peterson, R. A. (1978). The production of cultural change: The case of contemporary country music. Social Forces, 45, 292-314.

Peterson, R. A. (1992). Understanding audience segmentation: From elite and mass to omnivore and univore. Poetics, 21, 243-258.

Peterson, R. A. (1997). Creating country music: Fabricating authenticity. Chicago: University of Chicago Press.

Polsky, N. (1969). Hustlers, beats, and others. Garden City, NY: Anchor Books.

Rogin, M. P. (1987). Ronald Reagan, the movie: And other episodes of political demonology. Berkeley: University of California.

Roy, W. G. (2002). Aesthetic identity, race, and American folk music. Qualitative Sociology, 25, 459-469.

Suttles, G. D. (1984). The cumulative texture of local urban culture. American Journal of Sociology, 90, 283-304.

Suttles, G. D. (1990). The man-made city. Chicago: University of Chicago Press.

Thornton, S. (1996). Club cultures: Music, media and subcultural capital. Hanover: Wesleyan University Press.

Zorbaugh, H. W. ([1929]1976). The Gold Coast and the slum. Chicago: University of Chicago Press.

Zukin, S. (1982). Loft living: Culture and capital in urban change. Baltimore: Johns Hopkins University Press.

Zukin, S. (1991). Landscapes of power. Berkeley: University of California Press.

Zukin, S. (1995). The cultures of cities. Cambridge: Blackwell. 